\title{
Determination of the light yield of organic scintillators
}

\author{
N.Z.Galunov, O.A.Tarasenko, V.A.Tarasov \\ Institute for Scintillation Materials, STC "Institute for Single Crystals", \\ National Academy of Sciences of Ukraine, \\ 60 Lenin Ave., 61001 Kharkiv, Ukraine
}

Received July 15, 2013

\begin{abstract}
The paper analyzes the reasons of a distinction in the values of the light output and the light yield obtained by different authors for organic scintillators. The comparison method was used to determinate update values of the light output and the light yield for organic single crystals of anthracene, stilbene, $p$-terphenyl and plastic scimtillator on the base on polystyrene. These data correspond to characteristics of similar objects created in the Institute for Scintillation Materials, National Academy of Sciences of Ukraine, that are cited in the works of our foreign colleagues. By an example of stilbene crystals obtained by the same technology, it was shown that the spread in the light output values did not exceed $10 \%$.
\end{abstract}

Проведен анализ причин различий в значениях технического и абсолютного светового выхода органических сцинтилляторов, получаемых разными авторами. Методом сравнения получены уточненные данные по величине технического и абсолютного сцинтилляционного выхода органических монокристаллов антрацена, стильбена, $n$-терфенила и пластмассового сцинтиллятора на основе полистирола. Эти данные соответствуют характеристикам аналогичных объектов, созданных в Институте сцинтилляционных материалов НАН Украины, которые приводятся в работах наших зарубежных коллег. На примере монокристаллов стильбена, полученных по одной технологии, показано, что разброс величины технического светового выхода не превышал $10 \%$.

Визначення абсолютного світлового виходу органічних сцинтиляторів. М.З.Галунов, О.А.Тарасенко, В.О.Тарасов.

Проведено аналіз причин відмінностей у значеннях технічного та абсолютного світлового виходу органічних сцинтиляторів, які отримано різними авторами. Методом порівняння отримано уточнені дані величин технічного та абсолютного сцинтиляційного виходу органічних монокристалів антрацену, стильбену, $n$-терфенілу та пластмасового сцинтилятора на основі полістиролу. Ці дані відповідають характеристикам аналогічних об'єктів, створених в Інституті сцинтиляційних матеріалів НАН України, які наводяться у роботах наших закордонних колег. На прикладі монокристалів стильбену, отриманих за однією технологією, показано, що розкид величини технічного світлового виходу не перевищував $10 \%$.

\section{Introduction}

The light yield (LY) is an important characteristic of scintillators, i.e. materials those under an action of ionizing radiations generate light pulses which after that are converted by a photodetector an electrical charge. Usually, this value is given in the number of photons, which are produced when a scintillator absorb $1 \mathrm{MeV}$ of energy. The value of a pulse of electric current obtained on the photodetector output load is due to absorption of some energy by a scintillator. It is the light output (LO), the 
value that is experimentally measured. Then, by the reverse conversion the value of LY, which characterizes a scintillation material, is "restored". These procedures were described in some articles in detail [1, 2].

It is necessary to take into complete account the material, size, shape, surface treatment and packing of scintillator samples for correct determination of the LY. These characteristics determine the efficiency of light collection (light collection coefficient) on a photodetector. It should be also taken into account the adapting of the luminescence spectrum of a scintillator and the photosensitivity spectrum of a photomultiplier tube (PMT), as well as the quantum efficiency of PMT. It should be noted a large difference in approaches and results in characterizing the same scintillators that is observed for different authors. Back in 1987 E.Sakai emphasized [3] this situation.

At the present day this problem remains the same. Different groups of researchers report a success in obtaining new scintillators with the record values of the LY. Typically, the difference in light collection for different samples is ignored, i.e., in fact, the value, which is proportional to the LO (that is, the amount of light that reaches a PMT, but not originate in a scintillator) is used [4-6]. In some cases, the difference in a degree of spectral adapting of samples and PMT is not taken into account. In other words, some value, proportional to the photoelectron yield, is given [7].

Scintillators based on organic single crystals are characterized by the anisotropy of optical properties and a large block structure, with varying degrees of block disorder. These characteristics may be substantially different for the samples obtained by various methods. This fact leads to additional difficulties in determining the LY and, as the result, often, in the large variation of the LY-values obtained by various authors for the samples that are identical in their chemical composition.

The paper analyzes the reasons that cause the distinction in the LY-values of organic scintillators, obtained by different authors. For this purpose, we compared the values of the LY for different samples of the same types of scintillators reported in various publications, performed the comparative determination of the LY for the same samples basing of the results of various authors, including the results of the present work.

\section{Data review and analysis}

Tables 1 and 2 show the review data of, respectively, the LO and the LY of organic single crystals of anthracene, stilbene, $p$-terphenyl (both pure, and grown from a melt containing $0.1 \%$ of 1,4-diphenyl-1,3-butadiene), polystyrene plastic scintillators $(1.5 \%$ of $p$-terphenyl $+0.02 \%$ of POPOP), plastic scintillator $\mathrm{BC}-408$ and liquid scintillator BC-501A. Tables 1 and 2 demonstrate that the differences in the LO- and the LY-values reported by different authors for the same scintillators are significant.

The reasons for the large differences in the determination of the LY are the differences in the technology of production, treatment and packing of scintillators, aspects of the experimental instrumentation and methods of measurements, as well as the necessity of consideration of various factors when calculating the LY.

The development of the original methods of deep cleaning of raw materials and growing allowed us to produce structurally perfect organic single crystals with high LY [13]. This caused to appreciable difference between the values of the LY of organic scintillators presented in the catalogues of the leading manufacturers $[14,16,20]$ as well obtained in our studies (see [13], the review [21]). For example, according to [16], the LY of plastic scintillator BC-408 (EJ-200) is equal to $128 \%$, and liquid scintillator BC-501A (EJ-301/NE-213) is equal to $156 \%$ relatively to stilbene single crystal developed by the western companies. On the other hand, the results of our studies [21] shows that the LY of the plastic scintillator and the liquid scintillator of the of the same compositions is, respectively, $45 \%$ and $55 \%$ in comparison with structurally perfect stilbene single crystal produced in the Institute for Scintillation Materials NAS of Ukraine [13, 21]. The results of recent studies also indicate higher values of the LY of organic single crystals $[10,11,13$, $15,18]$ compared to earlier data $[8,9,16]$ and the data presented in the catalogues [14, $20]$ of the companies which specialize in production of plastic and liquid scintillators.

The differences in measurement techniques can also significantly effect on the LY-value. The analysis of methods of LY measurements of organic single crystals shows that, as in the case of inorganic scintillators [1-7], there is no the general approach to the measurement procedure, despite the IEC International Standard for the LO measurements of packed scintillators, 
Table 1. LO data (in photons per $\mathrm{MeV}$ ) of organic scintillators

\begin{tabular}{||c|c|c|c|c|c|c|c||}
\hline \hline Anthracene & $\begin{array}{c}\text { Trans- } \\
\text { stilbene }\end{array}$ & $\begin{array}{c}p- \\
\text { Terphenyl } \\
\text { (pure) }\end{array}$ & $\begin{array}{c}p- \\
\text { Terphenyl } \\
\text { (doped) }\end{array}$ & Polystyrene & $\begin{array}{c}\text { BC-408 (EJ- } \\
\text { 200) }\end{array}$ & $\begin{array}{c}\text { BC-501A } \\
\text { (EJ-301) }\end{array}$ & Ref. \# \\
\hline$\sim 9720^{1}$ & - & - & - & - & - & - & {$[8]$} \\
$(12480 \div 14220)^{2}$ & - & - & - & - & - & - & {$[9]$} \\
15860 & - & - & - & - & 11570 & 5086 & {$[10]$} \\
- & 10500 & - & - & - & - & - & {$[11]$} \\
11560 & 6720 & 6750 & 9780 & 4580 & - & - & {$[12]$} \\
\hline
\end{tabular}

Notes to Table 1:

1 - Our estimation is based on the data obtained in [8], according to which the scintillation yield of anthracene under electron irradiation is of about one photon per $60 \mathrm{eV}$ deposited in the crystal.

2 - For this estimation we used the values of the energy yield of anthracene single crystal (0.062 \pm 0.004$)$ [9] irradiated by electrons of ${ }^{137} \mathrm{Cs}$. The mean energy of a photon in anthracene luminescence spectrum (2.71 eV [12]) was used.

Table 2. LY data (in photons per $\mathrm{MeV}$ ) of organic scintillators

\begin{tabular}{|c|c|c|c|c|c|c|}
\hline Anthracene & Trans-stilbene & $\begin{array}{c}p- \\
\text { Terphenyl } \\
\text { (pure) }\end{array}$ & $\begin{array}{c}p \text {-Terphenyl } \\
\text { (doped) }\end{array}$ & Polystyrene & $\begin{array}{c}\mathrm{BC}-408 \\
(\mathrm{EJ}-200)\end{array}$ & Ref. \# \\
\hline $16672^{1}$ & - & - & - & - & - & [8] \\
\hline $21607 \div 24391^{2}$ & - & - & - & - & - & [9] \\
\hline 19399 & 10200 & 11727 & 15904 & 6313 & - & [12] \\
\hline 20000 & 14000 & - & 27000 & - & - & [13] \\
\hline- & - & - & - & - & $\sim 10000$ & [14] \\
\hline- & - & - & $35000 \pm 2000$ & - & $\sim 10000$ & [15] \\
\hline $15625^{3}$ & $7812^{3}$ & - & - & - & $\sim 10000$ & [16] \\
\hline- & 17800 & - & 28300 & - & - & [17] \\
\hline \multirow[t]{2}{*}{$19550^{4}$} & $19552^{4}$ & - & - & - & - & [18] \\
\hline & 15000 & - & - & - & - & [19] \\
\hline
\end{tabular}

Notes to Table 2:

1 - See the notes to Table 1 . The value of light collection coefficient $\tau_{e}=0.583$ was taken from [12].

2 - See the notes to Table 1 . The value of light collection coefficient $\tau_{e}=0.583$ was used.

3 - The calculation is based on the data [16] of the relative LY for anthracene, stilbene and plastic scintillator BC-408 (EJ-200). According to [14], the LY of BC-408 is equal to 10000 photons per $1 \mathrm{MeV}$.

4 - The samples obtained from a solution were studied in [18].

accepted in 2006 [22]. Attempts to universalize the results obtained by various authors using the same conversion coefficients may be incorrect because of the uncertainty of some conversion coefficients for the real samples.

\section{The method of LY measuring}

The relationship between a pulse height $(\mathrm{PH})$, generated at the output of the measuring circuit, and the LY of a scintillator is the following:

$$
P H=L Y \times K_{l c} \times K_{a v}^{\max } \times K_{p m t}^{s c} \times K,
$$

where $K_{l c}$ is the light collection coefficient, $K_{a v} \max$ is the maximum average quantum efficiency of a photocathode, $K_{p m t} s c$ is the coefficient of spectral matching of the photodetector and the scintillator, $K$ is a certain efficient coefficient of amplification of the measuring circuit including a PMT dynode. The product of the first two factors on the right side of Eq.(1) defines the LO, and the product of the first four factors defines the photoelectric yield ( $\left.L_{p h e}\right)$. $L_{p h e}$ is the number of photoelectrons emit- 
ted from a photocathode during the scintillator absorbs $1 \mathrm{MeV}$.

In the present work we used the method of determining the LY based on a comparison of pulse heights of the sample under investigation $\left(H P^{X}\right)$ and the reference sample $\left(H P^{R f}\right)$. Hereafter the upper indices $X$ and $R f$ refer to the sample under investigation and the reference sample, respectively. Comparing the positions of peaks or Compton edges of these samples $\left(P H^{X} / P H^{R f}\right)$ for the specific energies and finding the values of $L Y^{R f}, K_{l c}^{X}, K_{a v}^{\max X}, K_{p m t} s c X, K_{l c}^{R f}$, $K_{a v} \max R f, K_{p m t} s c{ }^{2}$, one can obtain the value of $L Y^{X}:$

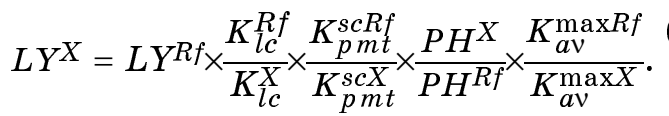

The value of $K_{a v}{ }^{\max } R f / K_{a v} \max X$ is close to one in the case of a small difference in cross-section dimensions of the samples. In this context Eq.(2) can be simplified as:

$$
L Y^{X}=L Y^{R f} \times \frac{K_{l c}^{R f}}{K_{l c}^{X}} \times \frac{K_{p m t}^{s c R f}}{K_{p m t}^{s c X}} \times \frac{P H^{X}}{P H^{R f}} .
$$

Light collection coefficients $K_{l c}$ were calculated using Monte Carlo simulation for certain values of transparency, surface treatment and packing of the scintillator. The coefficients $K_{a v}{ }^{\max }$ and data for calculation of $K_{p m t}{ }^{s c}$ were taken from the catalog [23]. To calculate $K_{p m t}{ }^{s c}$ luminescence spectra of the samples were also measured.

\section{Comparative results}

In [12] using the comparison method we calculated the LO and the LY for a series of organic scintillators (see Tables 1 and 2). The sample of $\varnothing 30 \times 5 \mathrm{~mm}^{2}$ stilbene single crystal was used the reference detector. The value of the LY assumed for this reference sample has been determined in [2] for a standard sample of stilbene.

The authors of the works [11, 19] run the measurements of LY for the samples of stilbene single crystals of our production. The higher values of the LY were obtained. To adjust this disagreement we carried out the comparative measurements of $\varnothing 40 \times 40 \mathrm{~mm}^{2}$ stilbene detector used by the authors in [2] and the single crystal of stilbene, studied in [12] as well as a series of other stilbene single crystals. It was found that their values of the LY are 1.41.5 times higher than the light LY of $\varnothing 40 \times 40 \mathrm{~mm}^{2}$ stilbene detector. In our opinion, this result may be explained by incor-

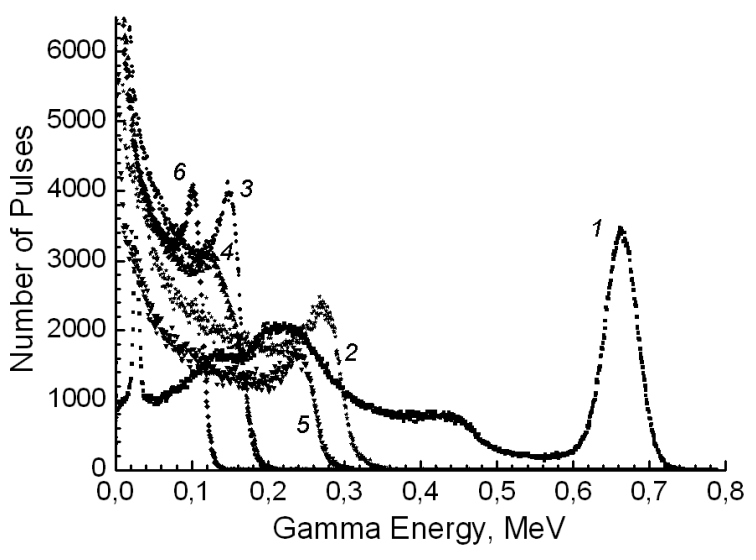

Fig. 1. Amplitude spectra of scintillators irradiated by photons of gamma radiation of ${ }^{137} \mathrm{Cs}$. Single crystals: $1-\mathrm{Nal}(\mathrm{TI})$ $\left(\varnothing 40 \times 40 \mathrm{~mm}^{2}\right), 2$ - anthracene $\left(\varnothing 20 \times 5 \mathrm{~mm}^{2}\right)$, 3 - stilbene $\left(\varnothing 30 \times 5 \mathrm{~mm}^{2}\right), 4$ - pure $p$-terphenyl $\left(\varnothing 30 \times 5 \mathrm{~mm}^{2}\right), 5-p$-terphenyl doped with $0.1 \%$ of 1,4-diphenyl-1,3-butadiene $\left(\varnothing 20 \times 5 \mathrm{~mm}^{2}\right)$. Plastic scintillator: $6-$ polystyrene $(1.5 \%$ of $p$-terphenyl $+0.02 \%$ of POPOP) $\left(\varnothing 30 \times 5 \mathrm{~mm}^{2}\right)$.

rect determination of the LY for the stilbene detector in [2], where the value of light collection coefficient $K_{l c}=0.7$ was used. This value was obtained before for $\mathrm{Nal}(\mathrm{TI})$ detector of the similar shape [24]. Thus, the LY-values for the scintillator material on the base of stilbene, currently produced in the Institute for Scintillation Materials, are 1.4-1.5 times higher than the value reported in [2]. Therefore the LY-values of the other scintillators obtained in [12] were also underrated.

In this paper the comparison method was also used for determination the LY-values of organic single crystals and plastic scintillator on the base on polystyrene. All samples had a height of $5 \mathrm{~mm}$ and were packed in the diffuse reflector (Tetratek). $\varnothing 40 \times 40 \mathrm{~mm}^{2} \mathrm{Nal}(\mathrm{Tl})$ detector with the value $\mathrm{LY}=4 \cdot 10^{4}$ photons per $\mathrm{MeV}$ was used as the reference detector. According to [24], light collection coefficient $K_{l c}$ for this detector with a matt surface and packed in a diffuse reflector was taken equal to 0.7.

A 9954A PMT [23] was used as a photodetector. The amplitude scintillation spectra of the samples were measured by a multi-channel amplitude analyzer AMA-0F. Calibration of the channel width in $\mathrm{MeV}$ of gamma radiation was performed by sources of ${ }^{22} \mathrm{Na},{ }^{60} \mathrm{Co},{ }^{137} \mathrm{Cs}$ and ${ }^{152} \mathrm{Eu}$. Fig. 1 shows the results of measurements of amplitude 
N.Z.Galunov et al. / Determination of the light yield ...

Table 3. Values of $K_{l c}$, LO and LY (in photons per MeV) of organic scintillators

\begin{tabular}{|c|c|c|c|c|c||}
\hline \hline Sample & Anthracene & Trans-stilbene & $\begin{array}{c}p \text {-Terphenyl } \\
\text { (pure) }\end{array}$ & $\begin{array}{c}p \text {-Terphenyl } \\
\text { (doped) }\end{array}$ & Polystyrene \\
LO & 17330 & 9670 & 9745 & 15345 & 6660 \\
$K_{l c}$ & 0.596 & 0.659 & 0.576 & 0.615 & 0.725 \\
LY & 29080 & 14700 & 16920 & 24950 & 9190 \\
\hline
\end{tabular}

scintillation spectra of the samples excited by gamma radiation photons of ${ }^{137} \mathrm{Cs}$.

The LO- and LY-values were determined by the method described in Section 3 of the present article by comparing the position of the maximum in the amplitude spectrum of $\mathrm{Nal}(\mathrm{TI})(0.662 \mathrm{MeV})$ and the positions of the Compton edges $(0.480 \mathrm{MeV})$ in the spectra of the organic scintillators under investigation. The results are shown in Table 3 .

The results of measurements of the LY of stilbene single crystals grown in the Institute for Scintillation Materials was recently reported in $[11,19]$. This allows a correct comparison of our results and the results of other authors. Comparison of the LO-value for the stilbene single crystal (Table 3) with the same value obtained in [11] (Table 1), as well as the LY-value (Table 3) with its analogue in [19] (see Table 2) indicates that the deviation in the results of measurements is not more than $10 \%$.

The validity of such an error in the measurements of various researchers is confirmed by the results of our studies of the relative LO of the samples of stilbene single crystals with the same size $\left(\varnothing 35 \times 10 \mathrm{~mm}^{2}\right)$ and produced by the same technology. During the measure scintillation pulses detected alternately from one of the opposite cylindrical bases (irradiation was performed from the side of the other base). As a result of such the measurements two different values of the relative LO were obtained for each sample. As an example Table 4 presents the results of such the measurements run for three samples of stilbene single crystal (\# \# 1,2,3). The maximum value of the LO is taken as $100 \%$. The minor value of LO for each the sample is given in parenthesis.

The spread in the experimental data shown in Table 4 does not exceed $10 \%$ and may be determined both by the spread in technological parameters of production of each specific sample of a detector and by irreducible methodological error of measurements.
Table 4 . The relative LO of stilbene single crystals $\varnothing 35 \times 10 \mathrm{~mm}^{2}$ (details are in the text)

\begin{tabular}{|c|c||}
\hline \hline Sample \# & Relative LO, \% \\
\hline 1 & $100(98.8)$ \\
2 & $90.4(89.9)$ \\
3 & $95.8(94.6)$ \\
\hline
\end{tabular}

\section{Conclusions}

There is a wide variety of approaches in determining the LY-value, which is the main characteristic of the scintillation materials [25]. As a result, the various data often are difficult to interpret in terms of their comparison. This problem unfortunately is not to be easy for organic scintillators. The obtained results and their analysis showed that the spread in the LY data for the specific type of a scintillator is determined not only by the aspects of design and performance of the experiment, but also by the details of the production technology. It will correctly to determine the LY for the specific sample of a scintillator. In addition, for each sample we need to determine the radioluminescence spectrum, the absorbtion coefficients of scintillation light, to provide a surface treatment, to use the reflectors with specific characteristics.

In this paper we presented updated data on the LO and LY (Table 3) for the major types of organic single crystals and standard plastic scintillator. These data are consistent with those obtained for similar systems developed in the Institute for Scintillation Materials by our foreign colleagues $[11,19]$. The important result is determination of the spread in the LO-values, which did not exceed $10 \%$ (Table 4). The results obtained in this work expand the database needed to develop the reference samples of organic scintillators for the LY certification.

\section{References}

1. M.Moszynski, M.Kapusta, M.Mayhugh et al., IEEE Trans. Nucl. Sci., 44, 1052 (1997).

2. E.Sysoeva, V.Tarasov, O. Zelenskaya, Nucl. Instrum. Meth. Phys. Res., A486, 67 (2002). 
3. E.Sakai, IEEE Trans. Nucl.Sci., NS-34, 418 (1987).

4. J.A.Mares, M.Nikl, A.Beitlerova et al., Opt. Mater., 24, 281 (2003).

5. M.A.Spurrier, P.Szupryczynskia, H.Rothfussa et al., J. Cryst. Growth, 310, 2110 (2008).

6. G.Rooh, H.J.Kim, S.Kim, Radiat.Meas., 45, 412 (2010).

7. S.Kawamura, J.H.Kaneko, M.Higuchi et al., IEEE Trans. Nucl. Sci., 56, 328 (2009).

8. M.Schott, Mol.Cryst.Liq.Cryst., 5, 229 (1969).

9. G.T.Wright, Proc.Phys. Soc., B68, 701 (1955).

10. A.Nassalski, M.Moszynski, A.Syntfeld-Kazuch, T.Swiderski, IEEE Trans. Nucl.Sci., 55, 1069 (2008).

11. J.Iwanowska, L.Swiderski, M.Moszynski et al., J.Instrum., 6, 1 (2011).

12. O.A.Tarasenko, N.Z.Galunov, V.D.Panikarskaya et al., Functional Materials, 19, 404 (2012).

13. CRYOS-beta Catalogue, http://www.cryosbeta.kharkov.ua/organic.php.

14. ELJEN TECHNOLOGY, Products, http://www.eljentechnology.com/index.php/ products.

15. M.Angelone, G.Battistoni, F.Bellini et al., http://arxiv.org/pdf/1305.0442v1.pdf (2013).

16. G.F.Knoll, Radiation Detection and Measurement, John Wiley \& Sons, Inc., New York (1999).
17. N.Z.Galunov, B.V.Grinyov, N.L.Karavaeva et al., IEEE Trans. Nucl.Sci., 56, 904 (2009).

18. G.Hull, N.P.Zaitseva, N.J.Cherepy et al., IEEE Trans. Nucl. Sci., 56, 899 (2009).

19. S.K.Lee, Y.H.Cho, B.H.Kang et al., Progr. Nucl. Sci. Techn., 1, 292 (2011).

20. Saint-Gobain Crystals, Organic Scintillation Materials, http://www.detectors.saint-gobain.com/uploadedFiles/SGdetectors/Docume nts/Brochures/Organics-Brochure.pdf.

21. N.Z.Galunov, V.P.Seminozhenko, Teoriya i Primenenie Radioluminestsentsii Organicheskih Kondensirovannyh Sred, Naukova Dumka, Kiev (1997) [in Russian].

22. Nuclear instrumentation - Housed scintillators - Measurement methods of light output and intrinsic resolution, IEC INTERNATIONAL STANDARD 62372, First edition 2006-02.

23. ET Enterprises Ltd. Photomultipliers, http://my.et-enterprises.com/pdf/9954B.pdf.

24. M.Globus, B.Grinyov, J.K.Kim, Inorganic Scintillators for Modern and Traditional Applications, Institute for Single Crystals, Kharkov (2005).

25. S.Derenzo, M.Boswell, M.Weber, K.Brennan, Lawrence Berkeley National Laboratory, Scintillation Properties, http://scintillator.lbl.gov. 